\title{
Field Trial of Methoxyflurane, Nitrous Oxide, and Trichloroethylene as Obstetric Analgesics
}

\author{
M. ROSEN,* F.F.A. R.C.s. ; W. W. MUSHIN, † F.R.C.S., F.F.A. R.c.s. ; P. L. JONES, $\ddagger$ F.F.A. R.C.S. ; E. V. JONES§
}

British Medical fournal, 1969, 3, 263-267

\begin{abstract}
Summary : In a field trial of 1,257 patients receiving $\checkmark$ methoxyflurane, trichloroethylene, and nitrousoxide/oxygen for the relief of pain in labour methoxyflurane has been shown to have certain advantages which support its use in midwifery practice. The trial confirms our objective method for screening an inhalational agent as an obstetric analgesic.
\end{abstract}

\section{Introduction}

Methoxyflurane has been shown by a comparison with trichloroethylene (Major et al., 1966) and with nitrous oxide (Jones et al., 1969a, 1969b) to have certain advantages over them as an obstetric analgesic. During each of these trials an anaesthetist was present continuously as an assessor. His presence may have affected the results, though it is hoped equally for each drug being compared. It is still necessary, therefore, to show whether the differences which emerged from these trials are still present if methoxyflurane were used in general midwifery practice. In addition it is important to determine whether any advantages which methoxyflurane might have would be sufficient to make the drug especially attractive for use by midwives.

\section{Method}

A field trial was conducted in eight maternity units in South Wales. The plan was discussed thoroughly with the medical and nursing staff in each hospital before the trial began. The trial was carried out under the supervision of a consultant anaesthetist in each hospital. Originally it was intended to compare methoxyflurane and trichloroethylene. Shortly after starting the trial we felt it desirable to include nitrous oxide because of parallel detailed studies in this department (Jones et al., 1969a, 1969b). Furthermore, we sensed that some midwives were disinclined to use trichloroethylene. The trial was therefore rearranged to compare methoxyflurane with a free choice of either trichloroethylene or nitrous oxide. The day on which either methoxyflurane or the choice of nitrous oxide or trichloroethylene could be used was randomized on a calendar which stood in the labour room. On Sundays the midwife had an open choice of agent.

The data were entered by the midwife on a self-coding chart suitably arranged for transference to Hollerith cards. Besides recording personal details and data about complications of pregnancy, this dealt with details of the anaesthetic inhaled; other drugs given; the duration of labour and method of delivery ; the condition of the baby; the midwife's opinion on the mother's condition during labour ; and the mother's opinion of the pain relief. The mother was questioned by her midwife immediately after delivery and again by the ward sister two days later.

Each hospital was visited by us at about weekly intervals, not only to ensure smooth running of the trial but also to ensure that the trial was being conducted so far as possible in a uniform manner. Comments by the midwife were noted, though special care was taken not to influence these.

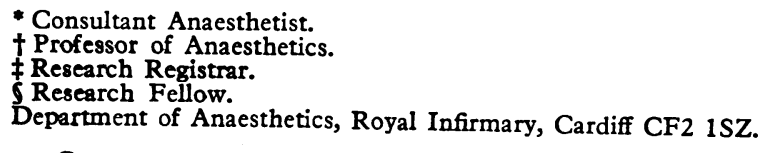

Nitrous-oxide/oxygen ( $50 \% / 50 \%$ v.v.) was given by the Entonox apparatus, trichloroethylene $(0.5 \%$ and $0.35 \%$ v.v. in air) by the Emotril and Tecota vaporizers, and methoxyflurane $(0.35 \%$ v.v. in air) by a modified Tecota, also known as the "Cardiff" inhaler. The calibration of each vaporizer was checked before the trial by gas chromatography and again at intervals during the trial. The midwives were instructed to use inhalation analgesia in their usual manner. No restrictions were placed on the use of other drugs such as pethidine.

After the trial was completed another questionary was sent by post to each of the participating midwives, in order to get a picture of the practical experience of the midwives and of their final opinions about methoxyflurane.

\section{Results}

\section{Randomization}

A total of 1,257 mothers were studied (Table I). The combined number of trichloroethylene and nitrous oxide patients is similar to that of methoxyflurane patients, because the midwife was allowed to use either trichloroethylene or nitrous oxide as an alternative to methoxyflurane. The difference in number between nitrous oxide and trichloroethylene is partly due to the rearrangement of the trial at the beginning. Trichloroethylene had a slight start over nitrous oxide.

\begin{tabular}{|c|c|c|c|c|c|c|}
\hline & & & $\begin{array}{l}\text { No. of } \\
\text { Cases }\end{array}$ & $\begin{array}{l}\text { Methoxy- } \\
\text { flurane }\end{array}$ & $\begin{array}{l}\text { Trichloro- } \\
\text { ethylene }\end{array}$ & $\begin{array}{l}\text { Nitrous } \\
\text { Oxide }\end{array}$ \\
\hline Total & . & .. & 1,257 & 598 & 394 & 265 \\
\hline \multicolumn{2}{|c|}{$\begin{array}{l}\text { Multiparae } \\
\text { Assisted deliveries } \\
\text { Caesarean section }\end{array}$} & $\begin{array}{l}\ldots \\
\because \\
\therefore\end{array}$ & $\begin{array}{r}703 \\
144 \\
8\end{array}$ & $\begin{array}{c}347(58 \% *) \\
68(11 \%) \\
5(1 \%)\end{array}$ & $\begin{array}{c}226(57.5 \%) \\
46(11.5 \%) \\
3(0.8 \%)\end{array}$ & $\begin{array}{c}130(49 \%) \\
30(11 \%) \\
0\end{array}$ \\
\hline
\end{tabular}

* The percentages are of each agent

There are significantly fewer multiparae in the nitrous oxide group than in the methoxyflurane group $(P<0.02)$ or in the trichloroethylene group $(P<0.05)$.

The number of multiparae in the nitrous oxide group is significantly lower than in each of the other two. A detailed examination of individual hospital results shows that when this difference is taken into account it does not affect the results of the midwives' assessment of pain relief or restlessness, the mothers' opinion of pain relief, or any of the other results reported in this paper. There is no significant difference between the groups as regards mode of delivery and the duration of the various stages of labour. The primiparae in the methoxyflurane group had shorter first stages than those who had the other agents.

Other Drugs (Table II).--Over half of the patients received pethidine within four hours of the beginning of inhalation, but there is only a negligible difference between the groups. Of those mothers who had pethidine, $5.7 \%$ had had more than

TABLE II.-Distribution of Administration of Drugs

\begin{tabular}{|c|c|c|c|c|c|c|c|c|}
\hline \multirow{2}{*}{\multicolumn{2}{|c|}{ Agent }} & \multicolumn{2}{|c|}{ No Drugs } & \multicolumn{2}{|c|}{ Pethidine } & \multicolumn{2}{|c|}{ Others } & \multirow{2}{*}{ Total } \\
\hline & & No. & $\%$ & No. & $\%$ & No. & $\%$ & \\
\hline $\begin{array}{l}\text { Methoxyflurane .. } \\
\text { Trichloroethylene } \\
\text { Nitrous oxide . . }\end{array}$ & $\begin{array}{l}\ldots \\
\cdots\end{array}$ & $\begin{array}{r}238 \\
151 \\
87\end{array}$ & $\begin{array}{l}40 \\
38 \\
33\end{array}$ & $\begin{array}{l}333 \\
228 \\
166\end{array}$ & $\begin{array}{l}56 \\
58 \\
63\end{array}$ & $\begin{array}{l}27 \\
15 \\
12\end{array}$ & $\begin{array}{l}4 \\
4 \\
4\end{array}$ & $\begin{array}{l}598 \\
394 \\
265\end{array}$ \\
\hline & & 476 & 38 & 727 & 58 & 54 & 4 & 1,257 \\
\hline
\end{tabular}

No significant difference between agents. 
$150 \mathrm{mg}$. within four hours of inhalation. Other drugs such as morphine were given to only a very small number of mothers in each group.

Duration of Inhalation (Fig. 1).-The duration of inhalation of methoxyflurane is shorter than that of nitrous oxide $(\mathbf{P}<0.02)$ and of trichloroethylene $(\mathbf{P}>0.3)$. This relates to the shorter first stages of the primiparae in the methoxyflurane group.

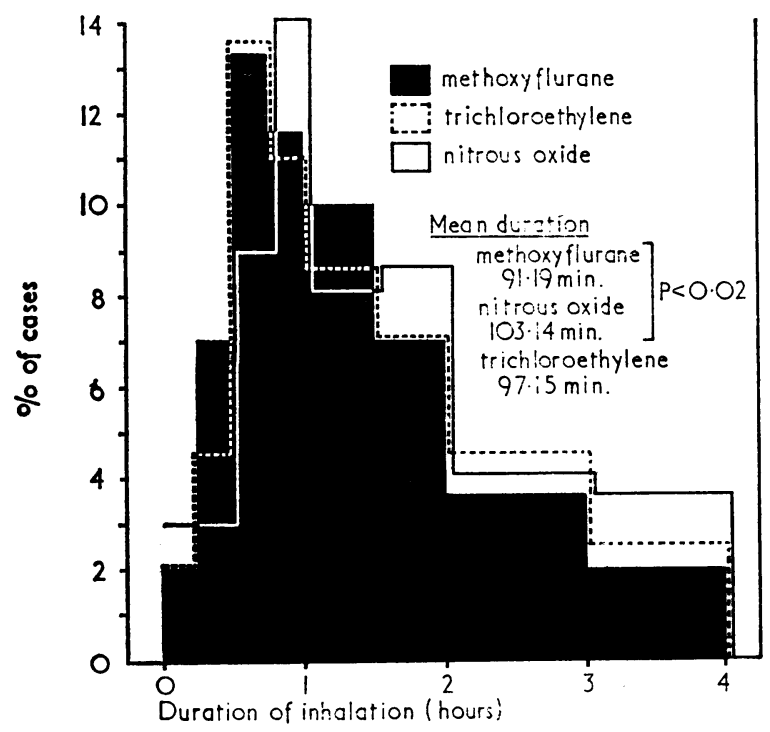

FIG. 1.-Distribution of duration of inhalation.

\section{Pain Relief}

Mothers' Opinion (Table III).-There is no great difference between any of the drugs. Thirty-five per cent. of all the mothers changed their mind at the second questioning, but the changes in either direction made little difference to the results.

\begin{tabular}{|c|c|c|c|c|c|c|c|c|c|}
\hline \multirow{2}{*}{ Agent } & \multicolumn{2}{|c|}{ Complete } & \multicolumn{2}{|c|}{ Considerable } & \multicolumn{2}{|c|}{ Slight } & \multicolumn{2}{|c|}{ None } & \multirow{2}{*}{ Total } \\
\hline & No. & $\%$ & No. & $\%$ & No. & $\%$ & No. & $\%$ & \\
\hline $\begin{array}{l}\text { Methoxy- } \\
\text { furane ... } \\
\text { Trichloro- } \\
\text { ethylene } \\
\text { Nitrous oxide }\end{array}$ & $\begin{array}{l}69 \\
47 \\
29\end{array}$ & $\begin{array}{l}11.5 \\
12 \\
11\end{array}$ & $\begin{array}{l}352 \\
235 \\
161\end{array}$ & $\begin{array}{l}59 \\
60 \\
61\end{array}$ & $\begin{array}{r}154 \\
98 \\
66\end{array}$ & $\begin{array}{l}26 \\
25 \\
25\end{array}$ & $\begin{array}{r}23 \\
14 \\
9\end{array}$ & $\begin{array}{r}3.5 \\
3 \\
3\end{array}$ & $\begin{array}{l}598 \\
394 \\
265\end{array}$ \\
\hline & 145 & $\overline{11.5}$ & 748 & $\overline{59.5}$ & 318 & 25.5 & 46 & 3.5 & 1,257 \\
\hline
\end{tabular}

Opinion of Multiparae (Table IV).-Fifty-five per cent. of the multiparous mothers considered the labour was better with methoxyflurane than their previous labours, compared with $42 \%$ who had trichloroethylene and $35 \%$ who had nitrous oxide. The difference between methoxyflurane and trichloroethylene is significant $(P<0.01)$ and that between methoxyflurane and nitrous oxide highly significant $(P<0.001)$. After the delivery $30 \%$ of all the multiparae changed their mind. The differences are still present between the drugs, though they are not now significant.

TABLE IV.-Multiparae's Opinion

\begin{tabular}{|c|c|c|c|c|c|c|c|c|c|}
\hline \multirow{2}{*}{ Agent } & \multicolumn{2}{|c|}{ Better } & \multicolumn{2}{|c|}{ Same } & \multicolumn{2}{|c|}{ Worse } & \multicolumn{2}{|c|}{ Don't Know } & \multirow{2}{*}{ Total } \\
\hline & No. & $\%$ & No. & $\%$ & No. & $\%$ & No. & $\%$ & \\
\hline \multirow{3}{*}{$\begin{array}{l}\text { Methoxy- } \\
\text { flurane .. } \\
\text { Trichloro- } \\
\text { ethylene } \\
\text { Nitrous oxide }\end{array}$} & 189 & 55 & 62 & 18 & 32 & 9 & 64 & 18 & 347 \\
\hline & $\begin{array}{l}94 \\
45\end{array}$ & $\begin{array}{l}42 \\
35\end{array}$ & $\begin{array}{l}66 \\
33\end{array}$ & $\begin{array}{l}29 \\
25\end{array}$ & $\begin{array}{l}22 \\
18\end{array}$ & $\begin{array}{l}10 \\
14\end{array}$ & $\begin{array}{l}44 \\
34\end{array}$ & $\begin{array}{l}19 \\
26\end{array}$ & $\begin{array}{l}226 \\
130\end{array}$ \\
\hline & 328 & 47 & 161 & 23 & 72 & 10 & 142 & 20 & 703 \\
\hline
\end{tabular}

Midwives' Opinion (Table V).-The midwives considered that more patients who had methoxyflurane $(14 \%)$ were excellent than were those who had nitrous oxide $(7 \%)(P<0.01)$. The number considered excellent and good is also significantly more for methoxyflurane $(53 \%)(\mathrm{P}<0.01)$ and for trichloroethylene $(49 \%)(P<0.02)$ than for nitrous oxide.

TABLB V.-Midwives' Opinion of Pain Relief

\begin{tabular}{|c|c|c|c|c|c|c|c|c|c|}
\hline \multirow{2}{*}{ Agent } & \multicolumn{2}{|c|}{ Excellent } & \multicolumn{2}{|c|}{ Good } & \multicolumn{2}{|c|}{ Adequate } & \multicolumn{2}{|c|}{ Inadequate } & \multirow{2}{*}{ Total } \\
\hline & No. & $\%$ & No. & $\%$ & No. & $\%$ & No. & $\%$ & \\
\hline \multirow{3}{*}{$\begin{array}{l}\text { Methoxy- } \\
\text { furane .. } \\
\text { Trichloro- } \\
\text { ethylene } \\
\text { Nitrous oxide }\end{array}$} & 81 & 14 & 235 & 39 & 225 & 38 & 57 & 9 & 598 \\
\hline & $\begin{array}{l}43 \\
19\end{array}$ & $\begin{array}{r}11 \\
7\end{array}$ & $\begin{array}{r}148 \\
92\end{array}$ & $\begin{array}{l}38 \\
35\end{array}$ & $\begin{array}{l}161 \\
129\end{array}$ & $\begin{array}{l}41 \\
49\end{array}$ & $\begin{array}{l}42 \\
25\end{array}$ & $\begin{array}{r}10 \\
9\end{array}$ & $\begin{array}{l}394 \\
265\end{array}$ \\
\hline & 143 & 11 & 475 & 38 & 515 & 41 & 124 & 10 & 1,257 \\
\hline
\end{tabular}

\section{Nausea and Vomiting}

Immediately after delivery $23 \%$ of the methoxyflurane patients, $22 \%$ of the trichloroethylene patients, and $19 \%$ of the nitrous oxide patients said they felt sick. Of these, $7.5 \%$ of the methoxyflurane group, $6 \%$ of the trichloroethylene group, and $7.5 \%$ of the nitrous oxide group vomited. There is no significant difference between the agents for any of these figures.

\section{Restlessness}

Midwives' Opinion.-There is no significant difference between the results for the three agents (Table VI). Nevertheless, when those who had not had pethidine are considered (Fig. 2) there is significantly less restlessness with methoxyflurane than with nitrous oxide $(P<0.05)$. Where pethidine had been given there is no difference between the agents. If the methoxyflurane patients are considered alone, those who did not have pethidine were significantly less restless than those who did $(P<0.01)$. Trichloroethylene patients showed a similar difference $(P<0.01)$. Nitrous oxide patients had the same degree of restlessness whether pethidine had been given or not.

\begin{tabular}{|c|c|c|c|c|c|c|c|c|}
\hline \multirow{2}{*}{ Agent } & & \multicolumn{2}{|c|}{ Never } & \multicolumn{2}{|c|}{ Short Periods } & \multicolumn{2}{|c|}{ Long Periods } & \multirow{2}{*}{ Total } \\
\hline & & No. & $\%$ & No. & $\%$ & No. & $\%$ & \\
\hline $\begin{array}{l}\text { Methoxyflurane .. } \\
\text { Trichloroethylene } \\
\text { Nitrous oxide . }\end{array}$ & $\ddot{x}$ & $\begin{array}{r}242 \\
153 \\
95\end{array}$ & $\begin{array}{l}41 \\
39 \\
36\end{array}$ & $\begin{array}{l}310 \\
206 \\
157\end{array}$ & $\begin{array}{l}52 \\
52 \\
59\end{array}$ & $\begin{array}{l}46 \\
35 \\
13\end{array}$ & $\begin{array}{l}7 \\
9 \\
5\end{array}$ & $\begin{array}{l}598 \\
394 \\
265\end{array}$ \\
\hline & & 490 & 39 & 673 & 53.5 & 94 & $7 \cdot 5$ & 1,257 \\
\hline
\end{tabular}



Fig. 2.-Effect of pethidine on midwives' opinion of restlessness. 
Duration of Inhalation and Restlessness.-The incidence of restlessness is not significantly related to the duration of inhalation.

\section{Co-operation}

Midwives' Opinion (Table VII).-The degrees of co-operation were listed as satisfactory, drowsy, too drowsy, asleep, and unconscious. Several midwives considered that some cases did not fit any of these categories and added the word " uncooperative." There was no significant difference between the number of patients who were considered as uncooperative in the three groups. None of the patients in the trial became unconscious. The number of patients considered satisfactory in regard to co-operation in both the nitrous oxide group and the trichloroethylene group is significantly higher $(81 \%$ and $76 \%$ ) than in the methoxyflurane group $(69 \%)$. There is no significant difference between the trichloroethylene and nitrous oxide patients. If those patients graded as satisfactory and drowsy are combined-the patients who would normally be considered by a midwife as adequately co-operative-there is no significant difference between the agents.

\begin{tabular}{|c|c|c|c|c|c|c|c|c|c|c|c|}
\hline \multirow{2}{*}{ Agent } & \multicolumn{2}{|c|}{$\begin{array}{c}\text { Satis- } \\
\text { factory }\end{array}$} & \multicolumn{2}{|c|}{ Drowsy } & \multicolumn{2}{|c|}{$\begin{array}{c}\text { Too } \\
\text { Drowsy }\end{array}$} & \multicolumn{2}{|c|}{ Asleep } & \multicolumn{2}{|c|}{$\begin{array}{c}\text { Unco- } \\
\text { operative }\end{array}$} & \multirow[t]{2}{*}{ Total } \\
\hline & No. & $\%$ & No. & $\%$ & No. & $\%$ & No. & $\%$ & No. & $\%$ & \\
\hline \multirow[t]{2}{*}{$\begin{array}{l}\text { Methoxyflurane .. } \\
\text { Trichloroethylene } \\
\text { Nitrous oxide }\end{array}$} & $\begin{array}{l}413 \\
298 \\
213 \\
\end{array}$ & $\begin{array}{l}69 \\
76 \\
81\end{array}$ & $\begin{array}{r}135 \\
68 \\
38 \\
\end{array}$ & $\begin{array}{l}23 \\
17 \\
14\end{array}$ & $\begin{array}{r}29 \\
14 \\
6\end{array}$ & $\begin{array}{l}5 \\
4 \\
2\end{array}$ & $\begin{array}{r}13 \\
5 \\
1\end{array}$ & $\begin{array}{l}2 \\
1 \\
1\end{array}$ & $\begin{array}{l}8 \\
9 \\
7\end{array}$ & $\begin{array}{l}1 \\
2 \\
2\end{array}$ & $\begin{array}{l}598 \\
394 \\
265\end{array}$ \\
\hline & 924 & $73 \cdot 5$ & 241 & 19 & 49 & 4 & 19 & 1.5 & 24 & 2 & 1,257 \\
\hline
\end{tabular}

Significantly higher percentag e of nitrous oxide group $(P<0.001)$ and of trichloro ethylene group $(\mathbf{P}<0.05)$ were satisfactory than of the methoxyflurane group.

Midwives' Opinion about Concentration of Agents (Table VIII).-The majority of the midwives $(79 \%)$ were satisfied with nitrous oxide, though $14 \%$ thought it could be stronger. Seventy-six per cent. were satisfied with trichloroethylene, and about equal numbers requested stronger and weaker concentrations. With methoxyflurane $69 \%$ of the midwives were satisfied and almost equal numbers $(12 \%$ and $11 \%)$ requested stronger and weaker concentrations. A larger proportion ( $8 \%$ ) could not make up their minds about methoxyflurane. These results seem to indicate that the midwives on the whole were satisfied with the concentrations of the two vapours. The difference between those who wanted the same concentration of nitrous oxide $(79 \%)$ and those who wanted the same concentration of methoxyflurane $(69 \%)$ is highly significant $(\mathbf{P}<0.001)$. The same is true in comparing trichloroethylene and methoxyflurane $(\mathrm{P}<0.05)$.

\begin{tabular}{|c|c|c|c|c|c|c|c|c|c|}
\hline \multirow{2}{*}{ Agent } & \multicolumn{2}{|c|}{ Same } & \multicolumn{2}{|c|}{ Stronger } & \multicolumn{2}{|c|}{ Weaker } & \multicolumn{2}{|c|}{ Don't Know } & \multirow{2}{*}{ Total } \\
\hline & No. & $\%$ & No. & $\%$ & No. & $\%$ & No. & $\%$ & \\
\hline $\begin{array}{l}\text { Methoxy- } \\
\text { flurane .. } \\
\text { Trichloro- }\end{array}$ & 412 & 69 & 72 & 12 & 64 & 11 & 50 & 8 & 598 \\
\hline $\begin{array}{l}\text { ethylene } \\
\text { Nitrous oxide }\end{array}$ & $\begin{array}{l}299 \\
213\end{array}$ & $\begin{array}{l}76 \\
79\end{array}$ & $\begin{array}{l}42 \\
36\end{array}$ & $\begin{array}{l}11 \\
14\end{array}$ & $\begin{array}{r}35 \\
5\end{array}$ & $\begin{array}{l}9 \\
3\end{array}$ & $\begin{array}{l}18 \\
11\end{array}$ & $\begin{array}{l}4 \\
4\end{array}$ & $\begin{array}{l}394 \\
265\end{array}$ \\
\hline & 924 & 73 & 150 & 12 & 109 & $8 \cdot 5$ & 79 & $6 \cdot 5$ & 1,257 \\
\hline
\end{tabular}

\section{Discontinuance of Original Inhalation}

Significantly fewer nitrous oxide cases had the inhalation abandoned than did methoxyflurane and trichloroethylene cases (Table IX). Frequently no reason was given.
TABLE IX.-Reasons and Incidence of Inhalation Abandoned

\begin{tabular}{|c|c|c|c|c|c|c|c|c|c|c|c|c|}
\hline \multirow{3}{*}{ Reason } & \multicolumn{4}{|c|}{ Methoxyflurane } & \multicolumn{4}{|c|}{$\begin{array}{c}\text { Nitrous } \\
\text { Oxide/Oxygen }\end{array}$} & \multicolumn{4}{|c|}{ Trichloroet h y lene } \\
\hline & \multicolumn{2}{|c|}{ Total } & \multicolumn{2}{|c|}{$\begin{array}{l}\text { Pethidine } \\
\text { Cases }\end{array}$} & \multicolumn{2}{|c|}{ Total } & \multicolumn{2}{|c|}{$\begin{array}{l}\text { Pethidine } \\
\text { Cases }\end{array}$} & \multicolumn{2}{|c|}{ Total } & \multicolumn{2}{|c|}{$\begin{array}{l}\text { Pethidin } \\
\text { Cases }\end{array}$} \\
\hline & No. & $\%$ & No & $\%$ & No. & $\%$ & No. & $\%$ & No. & $\%$ & No. & $\%$ \\
\hline $\begin{array}{l}\text { Ineffective } \\
\text { Too powerfut } \\
\text { Obstetrio reason } \\
\text { Other .. }\end{array}$ & $\begin{array}{l}18 \\
12 \\
9 \\
45\end{array}$ & $\begin{array}{l}3 \\
2 \\
1 \cdot 5 \\
7 \cdot 5\end{array}$ & $\begin{array}{r}14 \\
5 \\
5 \\
25\end{array}$ & $\begin{array}{l}78 \\
42 \\
55 \\
55\end{array}$ & $\begin{array}{l}6 \\
1 \\
2 \\
5\end{array}$ & $\begin{array}{l}2 \\
0.6 \\
0.8 \\
1.8\end{array}$ & $\begin{array}{l}6 \\
1 \\
1 \\
4\end{array}$ & $\begin{array}{r}100 \\
100 \\
50 \\
80\end{array}$ & $\begin{array}{r}6 \\
9 \\
6 \\
33\end{array}$ & $\begin{array}{l}1 \cdot 5 \\
2 \cdot 2 \\
1<5 \\
8\end{array}$ & $\begin{array}{r}4 \\
6 \\
3 \\
24\end{array}$ & $\begin{array}{l}67 \\
67 \\
50 \\
73\end{array}$ \\
\hline Total & 84 & 14 & 49 & 58 & 14 & 5 & 12 & 86 & 54 & $13 \cdot 2$ & 37 & 68 \\
\hline
\end{tabular}

\section{Midwives' Choice of Agent}

On Sunday the midwives were allowed a free choice of agent. Fifty-six per cent. (101) of patients were given methoxyflurane, $26 \%$ (47) nitrous oxide, and $18 \%$ (32) trichloroethylene. This indicates a significantly higher choice of methoryflurane $(\mathrm{P}<0.01)$. On $79 \%$ of the Sundays (22 out of 28$)$ the choice of methoxyflurane equalled or exceeded the combined use of the other two agents.

\section{Blood Loss}

The midwives estimated the blood loss in their usual way. There is no significant difference between the agents.

\section{The Baby}

Apgar Score.-The cumulative percentages of the Apgar scores at one minute have been calculated. There is no significant difference between the Apgar scores in each agent group. In those patients to whom pethidine had not been given the results show no significant difference between the scores. When pethidine had been given, however, there is a significantly higher percentage of babies with a low score in the nitrous oxide group than in either the methoxyflurane $(P<0.05)$ or the trichloroethylene groups $(P<0.01)$. On closer analysis the significant difference lies between the Apgar scores 7 and 10 (Fig. 3).

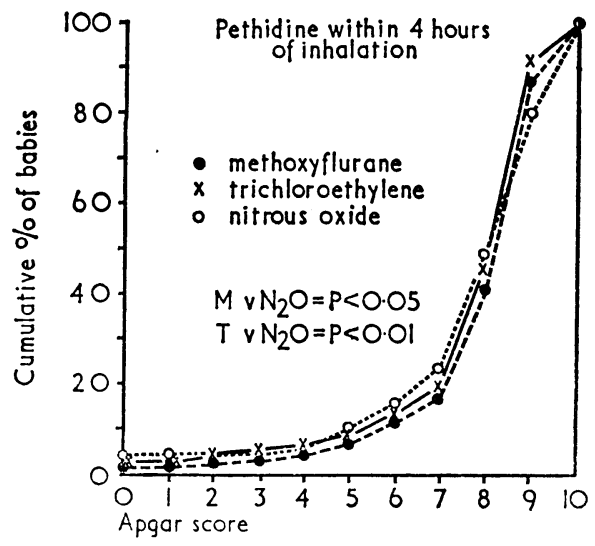

FIG. 3.-Inhalational analgesia. Apgar score at one minute.

Within each agent group there is a significant difference between the scores of those babies whose mothers had pethidine and those who had not (Fig. 4)

Treatment for Apnoea.-The incidences of artificial ventilation, tracheal intubation, and mortality are shown in Table X. Although slightly more babies had artificial ventilation in the methoxyflurane group than in the nitrous oxide group, this difference is not significant. Of the babies from each group who required artificial ventilation about $80 \%$ were born to mothers who had pethidine. 


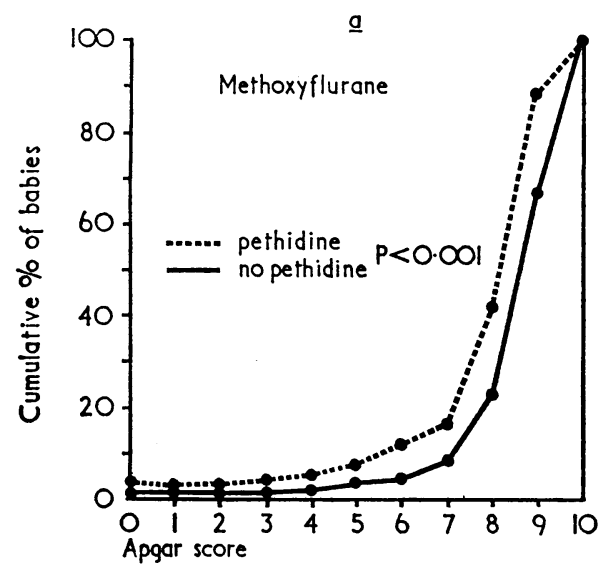

Fig. 4.-Inhalational analgesia. Apgar score at one minute.

TABLE X.-Incidence of Treatment for Apnoea and Mortality

\begin{tabular}{|c|c|c|c|c|c|c|c|c|c|}
\hline \multirow{3}{*}{ Agent } & \multicolumn{6}{|c|}{ Treatment for Apnoea } & & & \multirow{3}{*}{$\begin{array}{l}\text { Total } \\
\text { No. of } \\
\text { Cases } \\
\text { for } \\
\text { Each } \\
\text { Agent }\end{array}$} \\
\hline & \multicolumn{2}{|c|}{$\begin{array}{c}\text { Artificial } \\
\text { Ventilation }\end{array}$} & \multicolumn{2}{|c|}{$\begin{array}{l}\text { Artificial } \\
\text { Ventilation } \\
\text { Alone }\end{array}$} & \multicolumn{2}{|c|}{$\begin{array}{c}\text { Artificial } \\
\text { Ventilation } \\
\text { and Tracheal } \\
\text { Intubation }\end{array}$} & \multicolumn{2}{|c|}{ Mortality } & \\
\hline & No. & $\%$ & No. & $\%$ & No. & $\%$ & No. & $\%$ & \\
\hline Methoxyflurane & 32 & $5 \cdot 5$ & 13 & 2.5 & 19 & 3 & 3 & 0.5 & 598 \\
\hline $\begin{array}{l}\text { ethylene } \\
\text { Nitrous oxide }\end{array}$ & $\begin{array}{l}22 \\
14\end{array}$ & $\begin{array}{l}5 \cdot 5 \\
5: 5\end{array}$ & $\begin{array}{r}15 \\
8\end{array}$ & $\begin{array}{l}3 \cdot 5 \\
3 \cdot 5\end{array}$ & $\begin{array}{l}7 \\
6\end{array}$ & $\begin{array}{l}2 \\
2\end{array}$ & $\begin{array}{l}3 \\
2\end{array}$ & $\begin{array}{l}0.5 \\
0.5\end{array}$ & $\begin{array}{l}394 \\
265\end{array}$ \\
\hline
\end{tabular}

\section{Postal Questionary to Midwives}

Sixty per cent. (77) of the midwives replied. The mean time since their qualification as midwives was seven years. Thirtyfive per cent. of them were mothers themselves.

Before the trial began $85 \%$ were in favour of nitrous oxide and $50 \%$ in favour of trichloroethylene (47\% liked both agents). Forty-nine per cent. felt there was room for improvement as regards both agents. Entonox was the most commonly used method by $90 \%$ of the midwives.

From their experience of the trial $78 \%$ considered that methoxyflurane was an improvement on trichloroethylene and $53 \%$ felt it was an improvement on nitrous oxide.

The smell of trichloroethylene was objectionable to $42 \%$ and the smell of methoxyflurane to $35 \%$.

The replies indicated that the majority of them would welcome methoxyflurane as an inhalational analgesic, being, in their opinion, especially useful late in labour, in cases where labour was proceeding rapidly, and for apprehensive patients.

\section{Discussion}

This trial was undertaken partly to confirm that in routine midwifery practice our objective method of assessing obstetric inhalational analgesia by continuous administration could predict with a small number of patients the value of an inhaled obstetric analgesic. It was also undertaken to assess, in the circumstances of busy hospital maternity departments, whether methoxyflurane justified even wider clinical usage.

The assessment of an inhaled analgesic in a field trial posed different problems from our former closely controlled experiments. We were dependent for objective evidence on the opinions of midwives, whose experience ranged widely and who of ten held strongly entrenched and preconceived opinions of their own, and on the subjective opinions of the patients, many of whom were primiparae and had no previous experience with which to compare their present one. The trial showed that each of the three agents is reasonably satisfactory from the point of view of both the midwife and the patient. Indeed, the broad uniformity of the results is somewhat surprising considering the larger differences which emerged between methoxy- $\underline{b}$
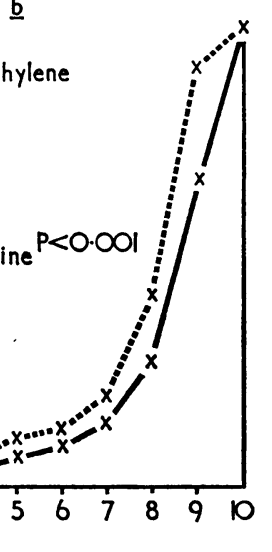

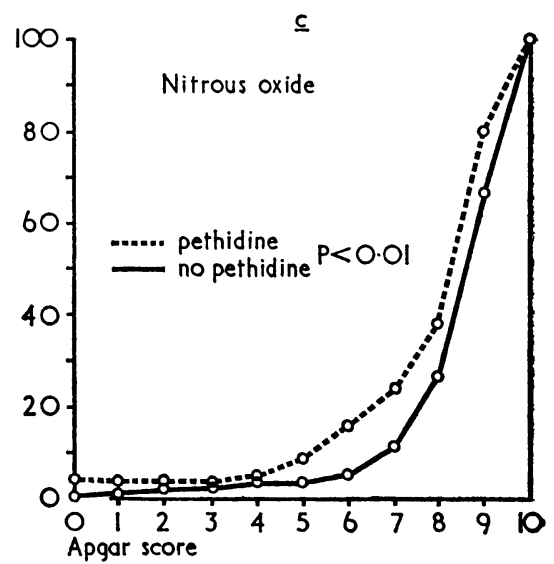

(a) Methoxyflurane; (b) trichloroethylene; (c) nitrous oxide. flurane and trichloroethylene, and between methoxyflurane and nitrous oxide in our other trials. The differences indicate the sensitivity of the objective method of assessment which we used.

We soon found in this trial that midwives often possess strong personal opinions about the relative merits of the agents with which they are familiar, either from practice or from hearsay. This is substantiated to some extent by the results from individual hospitals. When the results from all the hospitals are considered together there is a general similarity between the results from the three agents and only in certain details do differences become apparent.

Although in the assessment of obstetric pain relief the opinion of the sufferer must be paramount, the opinion of the midwife cannot be ignored, since the term "analgesia" in this connexion includes more than a subjective relief of pain by the patient. It includes also the retention of consciousness sufficient to permit the patient to co-operate fully with the midwife, and quiescence between contractions, since a restless patient is difficult to manage in these circumstances. If an inhalational analgesic therefore is to find a place, it must be acceptable in all these three respects both to patient and to midwife. So far as all the mothers were concerned methoxyflurane was as good as the other two. More than half as many again of the multiparae, however, thought methoxyflurane $(55 \%)$ better than the analgesia in their previous labours compared with those who had nitrous oxide $(35 \%)$. The trichloroethylene results $(42 \%)$ fell in between. The midwives also considered methoxyflurane better than nitrous oxide, though equal in this respect to trichloroethylene.

With regard to restlessness and co-operation the important point that emerges is that methoxyflurane seems best when used without previous administration of pethidine, though the reason for this is not clear. The patients who did not have pethidine were thought by the midwives to be less restless (significantly so) that those who did, though restlessness did not appear to be related to the duration of inhalation. The midwives' estimation of the patients' co-operation during labour was less "satisfactory" for methoxyflurane than for the others. Nevertheless, when their gradings of satisfactory and drowsy are considered together the differences between the agents disappear. Our explanation of this fact is based on our previous observation that patients given methoxyflurane tend to lie quietly with eyes closed though conscious and co-operative. This state of tranquillity may have been interpreted by the midwives as less satisfactory because of their unfamiliarity with methoxyflurane, resulting in their giving a grading of drowsy for such patients. It is important, if methoxyflurane is to be used by those unfamiliar with its effects, to have this explained to them.

We were anxious to obtain confirmation from this field trial that the concentration of the agents and in particular of methoxyflurane was neither too strong nor too weak. The midwives' opinion on this point was uniform in the case of 
nitrous oxide. Most thought the concentration was right, but those dissatisfied would have liked it stronger. In the case of trichloroethylene and methoxyflurane differences in opinion (a minority of the midwives would have liked a change) were balanced equally between stronger and weaker concentrations. Our inferences are that $50 \%$ nitrous oxide is perhaps a bit on the weak side but that the concentrations of trichloroethylene and methoxyflurane are about right.

We left it to the discretion of the midwives to stop the inhalation of any of the three agents whenever they thought it necessary. A larger number of patients who had methoxyflurane and trichloroethylene had the inhalation stopped compared with those who had nitrous oxide. It is not clear to us why this should have been so. Most of the reasons given were understandable, but in the case of methoxyflurane and trichloroethylene more midwives were unable to give a clear reason for their decision. We thought that this, too, may have been because of the apparent drowsiness caused by methoxyflurane and to a similar extent trichloroethylene, which the midwives may have been unable to reverse as rapidly as they would have been able to do in the case of nitrous oxide.

We have already commented on the disinclination by many of the midwives to use trichloroethylene. Our trial did not show up any particularly outstanding disadvantages of this agent and we are at a loss to account for the midwives' strong feeling. Although we gave the midwives the option of choosing either trichloroethylene or nitrous oxide on the randomized days when methoxyflurane was not to be used, in effect they gave an equal number of patients nitrous oxide and trichloroethylene. It seems that much of the prejudice against trichloroethylene has come about not so much from widespread practical experience but from strongly biased teaching. There is one popular text which not only prohibits smoking for 24 hours after trichloroethylene because of the danger of phosgene gas, but, more importantly, links trichloroethylene with foetal anoxia in premature labour, though the evidence for this is not stated. Another widespread feeling on the part of the midwives is that the $50 \%$ oxygen in the Entonox mixture gives a degree of protection against hypoxia, which is not present when breathing what is virtually room air in the case of trichloroethylene and methoxyflurane. If this feeling is strongly held it would not be difficult to arrange for oxygen enrichment of the methoxyflurane vapour and air mixture. Our studies of maternal blood levels in these circumstances indicate that the majority of mothers, instead of suffering from suboxygenation, in fact have raised oxygen tension, probably due to hyperventilation.

Although there were no differences between the three agents so far as the baby was concerned, the trial did show up clearly the pronounced effect of pethidine in depressing the Apgar scores and in being associated with the use of artificial ventilation and sometimes intubation of the babies. The effect of pethidine in causing foetal depression is apparent in the case of all three agents. In midwife teaching the danger of combining pethidine and trichloroethylene at the same time is invariably emphasized. This emphasis should also extend to nitrous oxide and to methoxyflurane.

In each of the four detailed studies methoxyflurane has been shown to be consistently associated with less nausea and vomiting than either trichloroethylene or nitrous oxide. We feel certain that this is a true effect. In this trial there has been no difference between the agents. We believe this once again confirms the experience of many studies that detailed inquiry and observations are essential to determine the true rate of nausea and vomiting (Mushin and Wood, 1944 ; Burtles and Peckett, 1957 ; Riding, 1960).

\section{Conclusions}

Our general conclusions are therefore as follows. Trichloroethylene does not appear to have any special advantage over the other two agents, though it does not appear to deserve the prejudice on the part of many midwives against it. Nitrous oxide is clearly a valuable obstetric analgesic, though much of its popularity with midwives undoubtedly arises from its present combination with oxygen and from the widespread feeling that this mixture not only has clear advantages in terms of oxygenation over the formerly used nitrous oxide and air but also over trichloroethylene. Methoxyflurane, in general, is at least as good as the other two with the possible exception of its smell. If pethidine is avoided, then methoxyflurane does seem to have definite advantages over nitrous oxide, and it may be that it has a special place as an alternative to the administration of pethidine when the pain-relieving powers of the Entonox mixture are insufficient later in labour. It also appears to be very effective for multiparae. This is noteworthy in view of the higher intensity of pain commonly experienced by these patients (A. Turnbull, personal communication, 1969).

It is clear from the postal questionary, and when the midwives were given a free choice of agent, that the majority would welcome the availability of methoxyflurane in their midwifery practice. Support for this view is given by the fact that the superintendent midwives of seven out of eight of the hospitals in the trial requested the return of the methoxyflurane inhalers so that the use of methoxyflurane could be continued.

With regard to the validity of the objective method of assessment which we developed in our other trials, this field trial has shown that it could indeed predict the value of an obstetric analgesic. Our objective method has been justified, since methoxyflurane proves to be a useful if not a valuable obstetric analgesic, and the predicted concentration for intermittent use proves to be the most effective when used in that way. As a result of this field trial and our former smaller trials we believe that methoxyflurane has advantages which would make its availability in obstetric practice welcomed. We have not seen any evidence of danger which would make its use by unsupervised midwives any less safe than trichloroethylene or nitrous oxide.

We doubt whether any further clinical trials of this nature are likely to expose any aspects which have not already been clarified. Consideration should now be given to approval of its use by unsupervised midwives, so that experience may accumulate in widespread clinical use rather than in the somewhat restricted circumstances of supervised controlled trials.

We would like to thank the obstetricians, anaesthetists, and midwives at Aberdare General Hospital ; Bridgend General Hospital ; Mount Pleasant Hospital, Swansea ; Morriston Hospital ; Neath General Hospital ; the Royal Gwent Hospital, Newport ; St. David's Hospital, Cardiff ; and St. James' Hospital, Tredegar ; without whose help and full co-operation the trial would have been impossible.

Two of us (E. V. J. and P. L. J.) were the grateful recipients of financial support as Research Fellows from the Board of Governors of the United Cardiff Hospitals.

We would also like to thank the department of medical statistics, Welsh National School of Medicine, and the department of medical illustration, Cardiff Royal Infirmary, for their helpful co-operation ; Messrs. Cyprane Ltd. for assistance with the vaporizers; and Abbott Laboratories Ltd. for supplies of methoxyflurane.

\section{REFERENCES}

Burtles, R., and Peckett, B. W. (1957). British fournal of Anaesthesia,

29, 114. British Medical fournal, 3, 255.

Jones, P. L., Rosen, M., Mushin, W. W., and Jones, E. V. (1969b). British Medical fournal, 3, 259.

Major, V., Rosen, M., and Mushin, W. W. (1966). British Medical fournal, 2, 1554 .

Mushin, W. W., and Wood, H. M. (1944). British Medical fournal, 1, 719. Riding, J. E. (1960). Proceedings of the Royal Society of Medicine, 53, 